\title{
Assessing Landscape Ecological Risk for a World Natural Heritage Site: a Case Study of Bayanbulak in China
}

\author{
Hui Shi', ${ }^{1,2}$ Zhaoping Yang ${ }^{1 *}$, Fang Han ${ }^{1}$, Tiange Shi ${ }^{1,2}$, Dong $\mathrm{Li}^{3}$ \\ 'Xinjiang Institute of Ecology and Geography, CAS, Urumqi 830011, China \\ ${ }^{2}$ University of Chinese Academy of Sciences, Beijing 100049, China \\ ${ }^{3}$ Tourism School, Xinjiang University of Finance and Economics, Urumqi Xinjiang 830012, China
}

Received: 17 February 2014

Accepted: 3 September 2014

\begin{abstract}
Wetland protection, floral and faunal resource management, and habitat migration are all concerns for the ecological risk of wetland landscapes. Indices of landscape-scale ecological risks have the potential to influence changes in landscape patterns, the conditions of endangered plants and animals, and influences from nature and humans. Semi-variation function and gravity center models were used to quantify risk area changes. The changes of landscape ecological risk were analyzed for Bayanbulak Wetland from 2000 to 2010. In addition to landscape and species distribution data, GIS technology and remote sensing were used in this study. Results show that landscape structure changed over the 10-year period, with high-cover grassland area decreasing the most. Landscape pattern index types also changed for the study area. The number of landscapetype patches to low-cover grassland decreased, the landscape fragmentation index of dry land and high-cover grassland was reduced, and the interference degree of middle-cover grassland increased over the study period. The index of landscape ecological risk decreased from 2000 to 2010, with the spatial structure changing from a single center concentration to a multi-center distribution. All varying ecological risk regions of gravity centers moved from the northeast to the southwest. The gravity migration of the Level 2 region moved the furthest. Additionally, evidence suggests that various threatening factors reduce the ecological function and systems of wetlands. These include climate change, biological invasion, human activities, and water pollution. This paper assesses the heritage site landscape ecological risk and calculates the gravity center change of the region, which can be formulated to enrich and develop the research of small- and medium-sized wetlands in cold, semi-arid climates.
\end{abstract}

Keywords: landscape ecological risk, spatial-temporal differentiation, wetland ecological management, habitat migration, Bayanbulak Wetland

\section{Introduction}

Wetlands are transitional zones located between terrestrial and aquatic ecological systems. They contain a multitude of flora and fauna resources [1]. Wetlands are impor-

*e-mail: yangzp@aliyun.com tant ecosystems and have been called 'the kidney of the earth' because of their prominent ecological purification effects [2]. The different types of wetland cover a total area of $14,800 \mathrm{~km}^{2}$, accounting for $0.9 \%$ of the land area in Xinjiang. Wetland ecosystems have become important habitats for countless floral and faunal species, which benefit ground water conservation, floodwater control, 
embankment protection, toxin and impurity transformations, nutrient retention, microclimate, and the prevention of saltwater intrusion [3, 4]. Globally, the total area of wetland has been decreasing at an accelerated rate, with an approximate reduction of $50 \%$ over the past 100 years [5, $6]$. This reduction is expected to cause the habitat of wetland animals and plants to change, causing habitat fragmentation. The biodiversity of wetlands may have decreased with the loss and fragmentation of habitats [7, 8]. Ecological risks for wetlands include human activities, climate change, the introduction of alien species, blind development, and so on [9]. These factors are all likely to amplify the reduction of wetland areas. Human activities are the most significant influence [10]. These activities include wetland cultivation, environment pollution, water resource over-use, water conservation project construction, urban expansion, and tourism [11, 12]. Scientific evaluation of wetland ecological risk is necessary to determine the early warning signs needed to protect wetlands [13].

The different landscape patterns of wetlands have an aesthetic appeal [14]. The landscape spatial heterogeneity and ecological holism affect the function and progression of the landscape [15]. The spatial distribution of landscape patterns changes over time, reflecting the matrix variation, functional transitions, and landscape evolution [16-18]. The direct influence of landscape transition alters the habitat for flora and fauna; with the loss and fragmentation of habitats, the number of species changes, especially for endangered species [19].

Due to the scale of wetland landscapes, remote sensing (RS) and geographic information systems (GIS) are effective tools for obtaining, storing, managing, and interpreting spatial and non-spatial data $[20,21]$. Remote sensing has been previously used to investigate and monitor landscape changes by capturing the same area at different time periods $[22,23]$. Moderate-resolution sensors can demonstrate landscape distribution, the composition of wetland in different land covers, habitat of vegetation and animals, and monitor the occurrence of invasive species [24].

Biodiversity encompasses ecological complexity with biology and the environment, covering a variety of connected ecological processes [25]. As an important index of community biological composition structure, biodiversity indicates the level of community organization, and also indirectly reflects the characteristics of community function by means of the relationship between structure and function [26]. Endangered species have particular roles in natural ecosystems, which are interdependent and maintain a delicate ecological balance with other species [27, 28]. Species diversity and changes in endangered species, as potential variations in the ecological environment, could help to quantify the degree of natural environmental interference.

Ecological risk is an important part of the characterization of ecosystem health and the complete condition [29, 30]. It has great influence on national security and social sustainable development [31]. In recent years, there have been numerous studies on ecological risk including pressure-state-response (PSR model) framework construction $[32,33]$, landscape ecological index selection [34-36], and other landscape ecology theory application [37, 38]. It is believed that the construction of the landscape ecological risk index combined with landscape pattern characteristics and species conditions for plants and animals. Research of landscape ecological risk would quantify habitat changes and characterize the risk probability or the possibility of adverse ecological effects for species, ecosystems, and the normal functioning of environments [39, 40].

Bayanbulak Wetland is the water source for the Kaidu and Kongque rivers. It plays an irreplaceable role in water conservation, ecological environmental protection, and climate regulation for residents downstream [41]. Since the 1990s scholars have studied the distribution of indicator species (such as the whooper swan), the surface water environment, climatic elements, and phytocenosis in the Bayanbulak Wetland [42-44]. Existing research of the Bayanbulak Wetland does not include a thorough analysis of the spatio-temporal changes of different landscape types, thriving and endangered species in high elevation, and cold climate wetland in the semi-arid region. In addition, the literature does not explain how to differentiate the ecological risk area in the Tianshan valley wetlands, the spatial variation of plant and animals habitats, and influencing factors.

This paper uses the spatial differential of landscape ecological risk index (LERI) to evaluate the wetland landscape of the Bayanbulak world heritage site. This study provides a reference for practical wetland protection policies to enrich and develop the research of small- and mediumsized wetlands in cold, semi-arid climates. The local environment, species, and landscape of the Bayanbulak Wetlands are affected by tourism, grazing, and mining. Therefore, environmental risk assessment is urgently needed to provide appropriate solutions.

\section{Materials and Methods}

\section{Study Area}

The Bayanbulak Wetland is located in Hejing County of the Bayingolin Mongol Autonomous Prefecture in the Xinjiang Uygur Autonomous Region. The boundary of the study area is consistent with Bayanbulak World Heritage Site, situated between latitude $42^{\circ} 37^{\prime} 15^{\prime \prime}$ to $43^{\circ} 0{ }^{\prime} 36^{\prime \prime}$ and longitude $83^{\circ} 38^{\prime} 45^{\prime \prime}$ to $84^{\circ} 38^{\prime} 17^{\prime \prime}$. The total study area is $1,895.38 \mathrm{~km}^{2}$ including Bayanbulak National Nature Reserve, which accounts for $57 \%$ of total area (Fig. 1). The elevation of the Bayanbulak basin is 2,300-2,600 m. The area has an arid continental climate, with short summers and long, freezing winters. The average annual temperature is $-4.6^{\circ} \mathrm{C}$, with high temperatures of $28.3^{\circ} \mathrm{C}$. Average annual precipitation is $276 \mathrm{~mm}$, annual evaporation is $1,128 \mathrm{~mm}$, and the average relative humidity is $69 \%$ [45].

The intermountain basin climate is different for the northern and southern slopes of Tianshan Mountain. It has three special climate features, which are the unique intermountain basin landform, the relatively humid climate, and the winter temperature inversion. The Tianshan Mountains 
are formed by three mountain chains, namely the North Middle and South Tianshan mountains. Among the mountains, basins of numerous sizes are produced. Bayanbulak Wetland is located in the Big Yuerdusi Basin. The elevation of Nalati Mountain is low, which separates Yili Valley and Bayanbulak Basin. Thus, water vapor from the Yili valley reaches the Bayanbulak Basin to form a moister climate than in other basins. By virtue of the surrounding mountains, especially the taller mountains to the north and south, the temperature of the Bayanbulak Basin undergoes inversion in the winter. During the winter, the temperature in the middle of the mountain is relatively high. The climate is mild, which favors the existence of winter pastures. Cooler summer temperatures and many wetlands on the Kaidu River bank provide the Bayanbulak heritage site with a suitable climate for the growth of forage grass and for migratory birds [46].

The unique climate of the Bayanbulak region gives it an alpine wetland landscape and the associated biodiversity characteristics. Due to the abundant precipitation and snow melt, countless rivers are formed. Large swamps appear when rivers flow through the widespread prairie [47]. According to vegetation classification in China, the vegetation in Bayanbulak is typical of the mountain grassland province of the south Tianshan slope and the Youerdusi basin sub-district. Of the 704 species of wild vascular plants in Bayanbulak, three species (namely Coeloglossum viride, Orchis latifolia, and Orchis umbrosa) are included in Appendices I, II, and III of CITES (2010). Additionally, 19 plant species are endemic to Xinjiang. There are 145 species of higher vertebrates in Bayanbulak, including 119 species of birds, such as cranes, egrets, golden eagles, barheaded geese, grey geese, whooper swans, tundra swans, and mute swans. Of the species present in Bayanbulak, 104 are listed on the Red List of IUCN (2010), such as Aythy anyroca, Limosa limosa, and Falco cherrug [48, 49].

On June 21, 2013, Xinjiang Tianshan was ratified as a world natural heritage site by the United Nations Educational Scientific and Cultural Organization (UNESCO), making it the $47^{\text {th }}$ world heritage site in China. The Bayanbulak, Bogda, Kalajun-kuerdening, and Tomur components constitute the Xinjiang Tianshan World Heritage Site. The Bayanbulak component stands out as the characteristic intermountain basin in Tianshan Mountain, as an alpine wetland ecosystem in an arid area, and reflects the landscape beauty of the Tianshan meander marsh [50].

In theory, the establishment of the heritage sites could potentially effect the development of stockbreeding, the local lifestyle, tourism, and infrastructure construction in Bayanbulak [51-53]. Grazing prohibition is implemented in heritage sites, therefore reducing the quantity of farmed livestock. Furthermore, enforceable ecological emigration could change the local lifestyle leading to a loss of the traditional nomadic culture. Tourism of the heritage site may attract a larger number of visitors. The government and local residents would financially benefit from the increase in tourism. Meanwhile, additional investment will be provided for construction, improving the infrastructure in the region [54, 55]. The Bayanbulak heritage site was established less than two years ago, many of the potential benefits have not yet been established. Therefore, it is difficult to judge the effects from a qualitative and experimental view.

\section{Methods}

Remote sensing is one of the key tools in monitoring local, regional, and global environmental issues [56]. It provides useful sensors and methods to investigate and monitor land use change, land cover mapping, zoning, and the environmental effects of human development [57]. Using remote sensing, information of landscape function and patterns can be obtained, which would reflect the stability of the landscape environment system in terms of resistance, persistency, swing, elasticity, or variability under spatial and temporal changes [58-60].

Integrity is a measure of the wholeness and intactness of the natural and/or cultural heritage and its attributes [61]. Operational Guidelines (2013) present the standard principle of integrity of the heritage site:

a) Includes all elements necessary to express its Outstanding Universal Value

b) Is of adequate size to ensure the complete representation of the features and processes that convey the property's significance

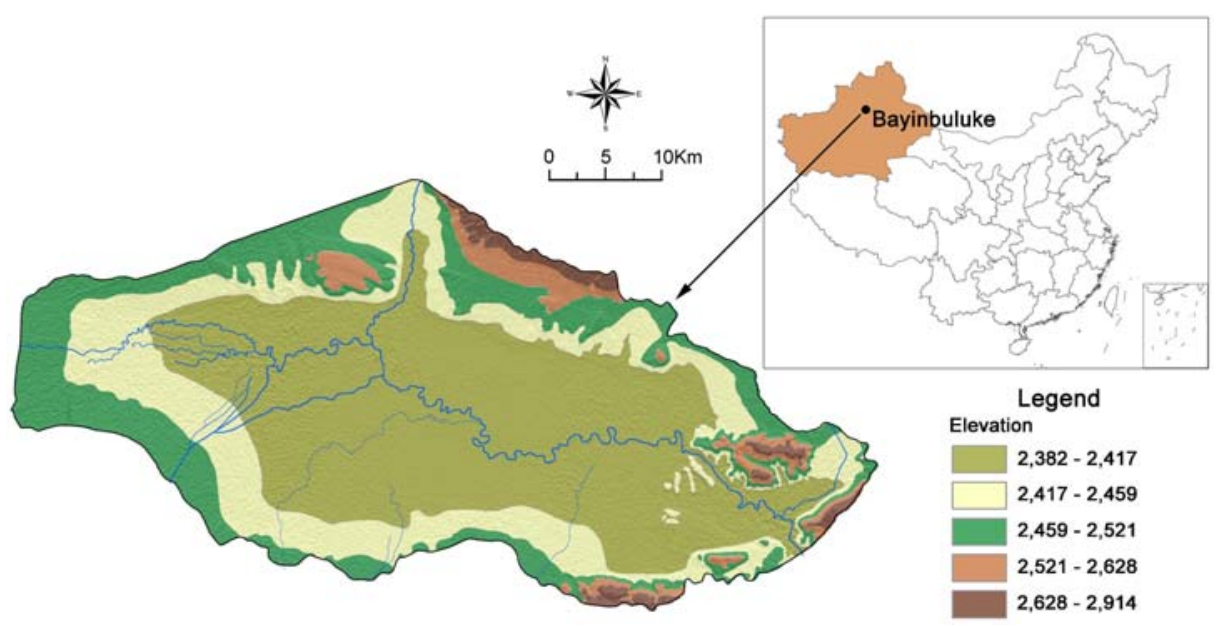

Fig. 1. Location of Bayanbulak wetland in China. 
Table 1. Acquisition data, spatial resolution, and source.

\begin{tabular}{|c|c|c|c|c|}
\hline Acquisition data & Time & Obtained data & Spatial resolution & Source \\
\hline Landsat TM & 27 June 2000 & No clouds & $30 \mathrm{~m}$ & http://store.usgs.gov/ \\
\hline Landsat TM & 2 August 2010 & No clouds & $30 \mathrm{~m}$ & http://store.usgs.gov/ \\
\hline DEM & - & - & $90 \mathrm{~m}$ & http://store.usgs.gov/ \\
\hline \multirow{3}{*}{$\begin{array}{l}\text { Digital data } \\
\text { (map of vegetation, } \\
\text { soil administration) }\end{array}$} & \multirow{3}{*}{16 October 2012} & \multirow{3}{*}{$\begin{array}{c}\text { The material declaration } \\
\text { for Xinjiang Tianshan } \\
\text { natural heritage }\end{array}$} & \multirow{3}{*}{-} & $\begin{array}{l}\text { The People's Republic of China } \\
\text { Vegetation Map }\end{array}$ \\
\hline & & & & The People's Republic of China Soil Map \\
\hline & & & & http://www.xjch.gov.cn/ \\
\hline $\begin{array}{l}\text { Temperature and } \\
\text { precipitation data }\end{array}$ & 12 November 2012 & Data from 2000-2007 & - & http://cdc.cma.gov.cn/ \\
\hline Grazing and tourism data & 20 November 2012 & Data from $2000-2010$ & - & http://www.xjhj.gov.cn/ \\
\hline Flora and fauna data & 20 December 2012 & $\begin{array}{c}\text { The material declaration } \\
\text { for Xinjiang Tianshan } \\
\text { natural heritage }\end{array}$ & - & $\begin{array}{l}\text { Appendix I, II and III of CITES (2010) } \\
\text { The Red List of IUCN (2010) National } \\
\text { Key Protected Wild Plants List (1999) }\end{array}$ \\
\hline
\end{tabular}

c) Suffers from adverse effects of development and/or neglect [50]

The parameters of landscape integrity may contain juxtaposing cadastral maps, historical document data, and aerial images. Landscape structure and function, as well as land-use and biodiversity characteristics, were chosen to comprehensively evaluate the landscape aesthetic value of the heritage site [61-64].

In landscape ecology, environmental sustainability is examined by observing and monitoring land use cover and change (LUCC), thus evaluating the effects of LUCC on ecosystem processes, functions, and services $[65,66]$. Wu (2013) defined landscape sustainability as a dynamic science among landscape pattern, landscape service, and human welfare with the use of space distribution across regional scales [67].

The literature suggests that the landscape has an intense relationship with the stability, integrity, and sustainability of the ecological environment [36]. This study combines the issues of the remote sensing data from Bayanbulak in 2000 (grazing increase) and 2010 (declaration for the world natural heritage) with the features of landscape pattern and species diversity to build the landscape ecological risk index (LERI). This paper assesses the heritage site landscape ecological risk and calculates the gravity center change of the region, in order to explore the change of space characteristics and the driving mechanism. Research into landscape ecological risk is beneficial for understanding the historical development of ecological risk, identifying areas at risk, and simulating ecological security progress. It is vital to realize the sustainable development of the ecological economy and society.

\section{Data Sources and Processing}

To construct a landscape-type distribution map, Landsat TM remote sensing images from 2000 and 2010 were used at a spatial resolution of $30 \mathrm{~m}$. The remote sensing images of path and row were 145 and 30. Acquisition image data that had no disturbance associated with clouds or seasonal influences were selected. For semi-arid regions in China, June to August is the optimum time to reduce disturbance factors. Digital elevation model (DEM) data were obtained from the United States Geological Survey at a spatial resolution of $90 \mathrm{~m}$. The digital data used in this study included the vegetation, soil, and administrative maps of Hejing County, China. Temperature and precipitation data for Bayanbulak, from 2000 to 2007, were obtained from the China Meteorological Data Sharing Service System. Grazing and tourism data were obtained from the Xinjiang and Hejing public government websites (Table 1).

The remote sensing images were combined with TM bands 1-5 and 7 (band 6 was excluded). Using ENVI 4.7 software, satellite bands 5, 4, and 3 were combined as RGB patterns with false color. Based on the Bayanbulak boundary shapefile of GIS and administrative map, false color images and other digital maps were cut with spatial analyst tools of the GIS 9.3 software. The other digital maps were rectified by ground control points to project into WGS_1984_UTM_Zone_44N coordinates. Using an interactive interpretation method, and combining field survey data with obvious object coordinates on field reconnaissance multiple times in the study area, information on landscape types was extracted and resulted in two period distribution maps.

Based on the physical condition of the study area, natural climate characteristics, and the national criterion of land use actuality classification, the landscape was divided into nine categories: wetland, low cover grassland (Low G), medium cover grassland (Medium G), full cover grassland (Full G), rural land (Rural L), bottomland, sand, woodland, and dry land (Dry L). To identify the obvious changes in wetland, rivers and swamps were combined into a "river marsh" category. Rural land included roads, rural residential areas and places for service facilities. Different grassland covers presented different landscape characteristics 
Table 2. Landscape classification in the mainstream of Bayanbulak.

\begin{tabular}{|c|c|c|}
\hline Landscape types categories & Landscape types & Description \\
\hline \multirow{2}{*}{ Wetland } & Reservoir and ponds & Artificial place for water storage \\
\cline { 2 - 3 } & River and channels & Natural river and man-made channel \\
\cline { 2 - 3 } & Lakes & Land with woody plants and water \\
\cline { 2 - 3 } & Swampland & Valley of land drained or irrigated by river system \\
\hline \multirow{2}{*}{ Low G } & Valley swamp & Coverage of grassland $<20 \%$ \\
\hline Medium G & - & Coverage of grassland between 20 to $50 \%$ \\
\hline \multirow{2}{*}{ Full G } & - & Coverage of grassland $>50 \%$ \\
\hline \multirow{2}{*}{ Rural L } & Road & Public way for the passage of vehicles and people \\
\hline \multirow{2}{*}{ Bottomland } & Construction land & Land used for building \\
\hline \multirow{2}{*}{ Sand } & Rural settlement & Land used for settlement \\
\hline \multirow{2}{*}{ Doodland } & Mudflat & Land used for benchland \\
\hline & Shrub land & Land of sand covering, without vegetation \\
\hline
\end{tabular}

and grassland was subsequently divided into low cover grassland, medium cover grassland, and full cover grassland (Table 2) [68, 69].

\section{Establishment of the LERI System}

Risk assessment of landscape ecologies can reflect environmental change and variations in plants and animals on a landscape scale. Ecological indices reflect the distribution of species habitat, migration, danger of extinction, and the number of changes in different landscape patterns $[5,70]$. The fragile index that measures landscape type can clearly show changes in the landscape pattern, area, heterogeneity, and matrix [35]. In this study, differences in the risk assessments of landscape ecology distribution were used to determine changes in the wetland environment [34]. The study area was divided into 1,092 units, each consisting of a $1 \times 1 \mathrm{~km}$ sample grid. The different landscape patterns present in each sampling unit showed the changes in species habitat and landscape matrix. The LERI of a single sample was measured by the degree of ecological risk.

$$
L E R I_{k}=\sum_{i=1}^{n} \frac{A_{k i}}{A_{k}}\left(E_{i} \times F_{i}\right)
$$

...where $L E R I_{k}$ is the landscape ecological risk index of sample $k, A_{k i}$ is the $k$ plot's $i$ landscape type area, $A_{k}$ is the total area of plot $k$, and $E_{i}$ and $F_{i}$ are the ecological and fragile index, respectively, of $i$ landscape type.

\section{The Ecological Index}

The Ecological Index reflects the integrity, importance, and natural quality of the landscape [38]. These factors were measured using the number of species, protection levels, and anti-interference levels of the different ecological systems in the study area [71]. The equation used was as follows:

$$
E_{i}=\alpha_{1} \cdot C_{i}+\alpha_{2} \cdot V_{i}+\alpha_{3} \cdot N_{i}
$$

...where $E_{i}$ is the ecological index of landscape type $i, \alpha_{i}$ is the weight of index, $C_{i}$ is the species conservation index, $V_{i}$ is the biodiversity index, and $N_{i}$ is the interference index. $C_{i}$ was most important for assessing ecological risk, as it reflects the degree of species protection, followed by $V_{i}$ and $N_{i}$. $N_{i}$ had a negative correlation with $E_{i}$. Using previous data, the values of $\alpha_{1}, \alpha_{2}$, and $\alpha_{3}$ were defined as $0.6,0.3$, and 0.1 , respectively $[17,34,72]$.

\section{- Species Conservation Index}

The proportion of endangered species, protected conditions, and the differences in landscape pattern can realistically reflect the condition of a habitat. Furthermore, the 
conservation status of a species and its importance allow effective identification of the level of species protection in different areas. The species conservation index was calculated as follows:

$$
C_{i}=\sum \lambda_{i} \frac{U_{i j}}{U_{j}}
$$

...where $C_{i}$ is the species conservation index for landscape type $i, U_{i j}$ is the level $j$ of protected species for landscape type $i, U_{j}$ is all level $j$-protected species in the region, and $\lambda_{j}$ is the level $j$-protected species ecological weights in the region. Species can be distinguished by the life habitats of animals in different landscape types. The values of $U_{i j}$ and $U_{j}$ can be obtained accordingly. The value of $\lambda_{j}$ is the product of two parts: one is level $j$ protected species of landscape types accounting for the proportion of the entire regional species protection, and the other is level $j$ weight of species importance [38, 73, 74].

Based on the method of expert consultation and the varying levels in four of the standard indices (such as the Red List of IUCN (2010), Appendices I, II, and III of CITES (2010), and National Key Protected Wild Plants List (1999)) the weighted levels of important protected animals and plants were defined as $7,5,3$, and $1[34,38]$.

\section{- Biodiversity Index}

Diversity is the primary characteristic of community, and reflects the complicated relationship between organisms and the environment. The index of biodiversity was calculated using Equation 4.

$$
V_{i}=M_{i} / M
$$

...where $V_{i}$ is the biodiversity index for landscape type $i, M_{i}$ is the species number for landscape type $i$, and $M$ is the species number in the study area.

\section{- Interference Index}

The degree of ecological disturbance, characterized by the extent of external disturbance in different landscape ecological systems, is reflected in natural features and the change in these processes following disturbances. Indices of fragmentation, separation, and dominance reflect the interference index of the landscape ecological systems, and they were used to construct the interference index. The species interference index was calculated as follows:

$$
N_{i}=a \cdot P_{i}+b \cdot S_{i}+c \cdot D_{i}
$$

...where $N_{i}$ is landscape interference index, $P_{i}, S_{i}$, and $D_{i}$ are the indices of fragmentation, separation, and dominance, respectively, and $a, b$, and $c$ are the respective weights. The computational formula of $P_{i}, S_{i}$, and $D_{i}$ came from the index of the Fragstats 3.3 software. In view of the importance of the landscape index, the contribution rate of landscape disturbance degree, and previously reported results, the weights were set as $0.5,0.3$, and 0.2 . Finally, the different dimension indices were normalized $[17,73,74]$.

\section{The Fragile Index}

Fragile index reflects the resistance ability of landscape types to external interference, and is positively correlated to the LERI [73]. Results from the literature and comparisons with similar study areas allowed the fragile levels of Full G, Medium G, Low G, Rural L, Dry L, woodland, sand, wetland, and bottomland to be respectively defined as $3,4,5,1,2,3,6,4$, and 7 . They were then normalized to the different dimension indices. In terms of the fragile characteristics, Rural L and Dry L were more stable than other landscape types because of the input negative management entropy by intensive human activity [34, 71].

\section{Establishment of Semi-Variation Function Model}

Regional ecological environment vulnerability is a spatial variable that shows both structural and random characteristics. The semi-variation function model was used to analyze the spatial dependence structure of ecological variables [6]. The ecological variables characterized spatial structure by the semi-variance as a function of lag distance [75].

$$
r(h)=\frac{1}{2 N(h)} \sum_{i=1}^{N(h)}\left[Z\left(x_{i}\right)-Z\left(x_{i}+h\right)\right]^{2}
$$

...where $N(h)$ is the semi-variance at lag distance $h, Z\left(x_{i}\right)$ is the sample $\mathrm{Z}$ in the actual position value of $x_{i}$, and $\mathrm{Z}\left(x_{i}+h\right)$ is sample $Z$ in the actual position value of $\left(x_{i}+h\right)$.

\section{Gravity Center Model}

A gravity center model was used to calculate the degree of gravity of ecological risk for the region. Through the aspect and distance of ecological risk, the gravity of a region changes and, accordingly, a change of trend and space range for different degrees can be directly quantified [76].

$$
\begin{gathered}
X_{i}=\sum_{i=1}^{n}\left(C_{t i} \times X_{t i}\right) / \sum_{i=1}^{n} C_{t i} \\
Y_{i}=\sum_{i=1}^{n}\left(C_{t i} \times Y_{t i}\right) / \sum_{i=1}^{n} C_{t i}
\end{gathered}
$$

...where $X_{i}$ and $Y_{i}$ are the gravity latitude and longitude coordinates in the risk region for year $i, \mathrm{n}$ is the number of patches in the risk region for the year, $C_{t i}$ is the area of patch $i$ in certain ecological risk region on the year $t$ and, lastly, $X_{t i}$ and $Y_{t i}$ are the geometric center coordinates of patch $i$ in a certain ecological risk region for year $t$. 
Table 3. Indices of landscape patter in Bayanbulak wetland.

\begin{tabular}{|l|c|c|c|c|c|c|c|c|c|c|c|c|}
\hline & \multicolumn{9}{|c}{2000} & \multicolumn{5}{c|}{2010} \\
\hline Landscape types & CA & NP & $P_{i}$ & $S_{i}$ & $D_{i}$ & $N_{i}$ & CA & NP & $P_{i}$ & $S_{i}$ & $D_{i}$ & $N_{i}$ \\
\hline Medium G & 94.85 & 6 & 0.05 & 0.56 & 0.07 & 0.13 & 356.91 & 28 & 0.19 & 0.32 & 0.25 & 0.55 \\
\hline Low G & 13.80 & 10 & 0.01 & 4.99 & 0.05 & 0.35 & 177.86 & 7 & 0.09 & 0.32 & 0.10 & 0.13 \\
\hline Rural L & 12.92 & 15 & 0.01 & 6.53 & 0.07 & 0.51 & 29.26 & 21 & 0.02 & 3.40 & 0.08 & 0.46 \\
\hline Dry L & 4.62 & 1 & 0.00 & 4.72 & 0.01 & 0.16 & 2.72 & 1 & 0.00 & 7.98 & 0.01 & 0.19 \\
\hline Woodland & 3.52 & 2 & 0.00 & 8.76 & 0.01 & 0.32 & 2.91 & 3 & 0.00 & 12.94 & 0.01 & 0.34 \\
\hline Sand & 17.69 & 13 & 0.01 & 4.44 & 0.06 & 0.39 & 33.28 & 14 & 0.02 & 2.44 & 0.05 & 0.31 \\
\hline Wetland & 811.53 & 13 & 0.43 & 0.10 & 0.37 & 0.30 & 613.73 & 14 & 0.32 & 0.13 & 0.30 & 0.30 \\
\hline Bottomland & 32.58 & 6 & 0.02 & 1.64 & 0.04 & 0.16 & 133.04 & 13 & 0.07 & 0.59 & 0.11 & 0.21 \\
\hline Full G & 903.89 & 27 & 0.48 & 0.13 & 0.48 & 0.60 & 545.69 & 27 & 0.29 & 0.21 & 0.32 & 0.51 \\
\hline
\end{tabular}

\section{Results}

\section{Descriptive Statistics of Landscape Structure Change and Ecological Variables}

\section{Landscape Structure Change in Bayanbulak}

Changes in the type of landscapes in the Bayanbulak Wetland are shown in Fig. 2. Table 3 contains the indices of landscape patterns from 2000 to 2010 . For the landscape area, the Full $\mathrm{G}$ coverage decreased by $39.63 \%$ between the years 2000 and 2010, and the wetland area was reduced by $197.80 \mathrm{~km}^{2}$. The area of Medium G increased by 262.06 $\mathrm{km}^{2}$, which corresponded to the largest change observed. Numbers of landscape type patches (NP) decreased for Low $\mathrm{G}$ due to the degradation of High and Medium $\mathrm{G}$ and the patches being connected to the big patches. High $P_{i}$ reflected that the landscape type tended to be dispersed. Low $P_{i}$ illustrated that patches of the different landscape types were concentrated into a larger patch. The $P_{i}$ of Dry $\mathrm{L}$, wetland, and Full $\mathrm{G}$ decreased, while the others increased. The $N_{i}$ of Medium G also increased. Sand, woodland, and bottomland increased slightly, and the others decreased. The change of $N_{i}$ for landscape patterns demonstrated that the degree of Medium G interference had the largest change over the 10 years studied. This is in accor- dance with grassland degradation under overgrazing and natural conditions, a phenomenon of medium and full cover grassland transforming into low cover grassland and bottomland (Table 3).

\section{Ecological Indices and Assumptions}

Species index was selected as an ecological risk indicator, according to the field survey of the study area [77]. The weight of the species and fragile indices in landscape patterns are shown in Fig. 3. The eco-indices contained the thriving and endangered species in different landscape patterns. The number of thriving and endangered species changed marginally over10 years, so it was hypothesized that $C_{i}$ and $V_{i}$ did not change either [72, 78]. Fragile index reflects the resistant ability of external interference for landscape types, the value of which is considered to be a result of human activity and the type of landscape. $F_{i}$ was assumed not to have changed (Fig. 3).

The $C_{i}$ and $V_{i}$ values that were related to the area of landscape types were highest for wetland. The other landscape types of $C_{i}$ tended to $0 . C_{i}$ was the endangered species index reflecting the distribution of rare protected species. There were more thriving and endangered species in wetland areas, especially endangered species, so the $C_{i}$ of species was strong when compared to other habitats.

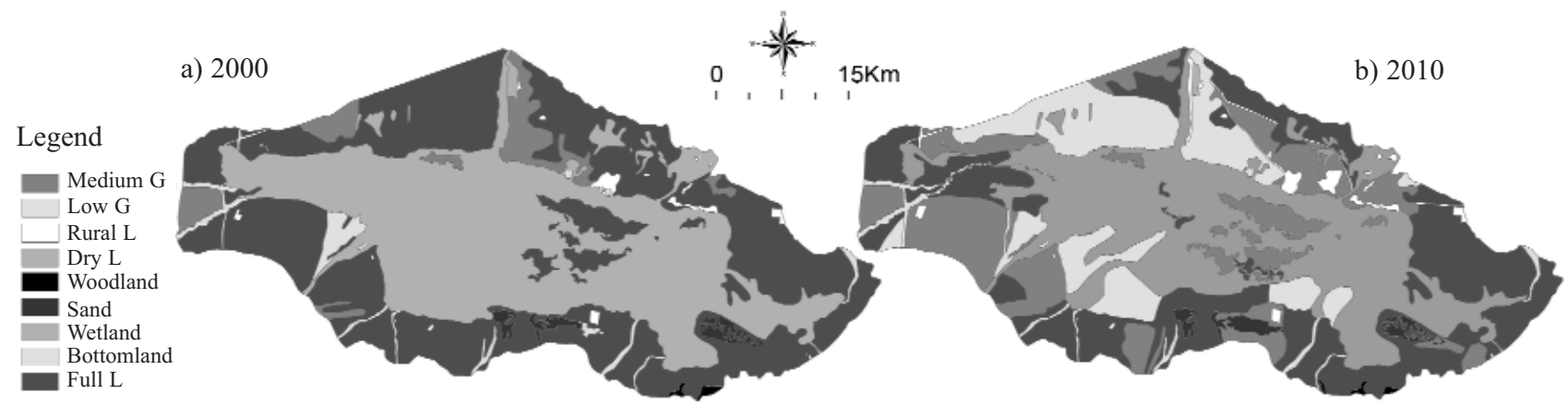

Fig. 2. Landscape types in Bayanbulak wetland in 2000 and 2010. 
Some $V_{i}$ tended to 0 , such as the landscape types of Rural L, Dry L, sand, and bottomland, while others changed from 0 to 0.1 . The $V_{i}$ for Full $\mathrm{G}$ was the second highest, because wetland and Full $\mathrm{G}$ are important habitats for all species. $F_{i}$ differed between landscape types, with values ranging from 0 to 0.3 .

\section{The Spatio-Temporal Distribution Characteristics of LERI}

\section{General Characteristics of LERI}

Following the formula, LERI was calculated and standardized for each quadrat in the area. A database was then built with GIS 9.3. The average LERI value for each quadrat was 0.036 in 2000 . The average LERI value in 2010 decreased to 0.025 . The LERI value for each quadrat was between $0-0.1243$ in 2000 and increased to $0-0.1245$ in 2010. The value of LERI of each different quadrat changed from 2000 to 2010. In 2010, the LERI of quadrats decreased, representing $56.26 \%$ of the entire quadrat area.

\section{Spatio-Temporal Distribution \\ Characteristics of LERI}

With the LERI of each quadrat defined as the value in the center of the quadrat point, the LERI data was shown to be normally distributed. LERI values were tested to satisfy the condition of semi-variation function analysis. With GS+, the effect of the spherical model was proved to be superior to other models. Following the result of the spherical model,

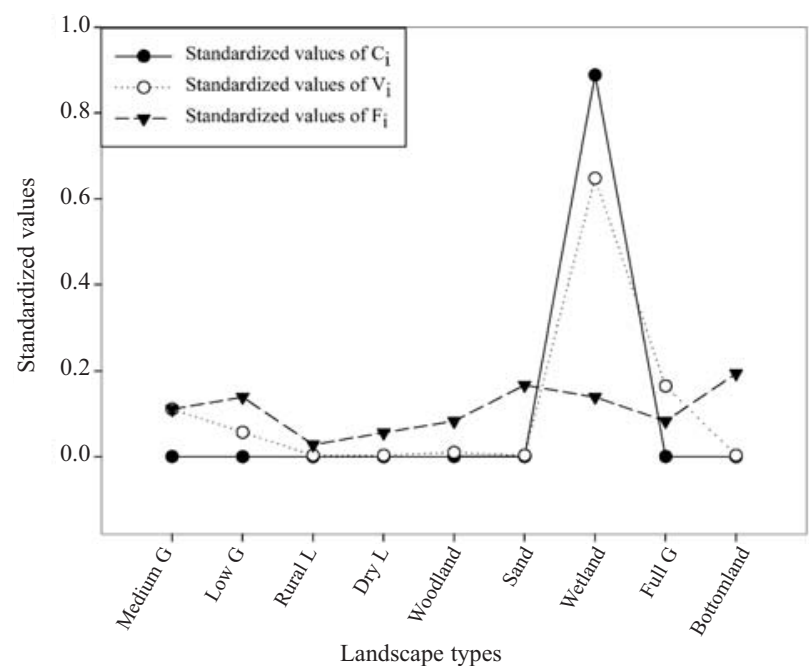

Fig. 3. Landscape pattern of Bayanbulak wetland for standardized values $C_{i}, V_{i}, F_{i}$.

$C_{i}: i$ landscape-type species conservation index

$V_{i}: i$ landscape-type biodiversity index

$F_{i}: i$ landscape-type resistant ability of external interference

$C_{i}, V_{i}$, and $F_{i}$ were all standardized. $C_{i}$ and $V_{i}$ were both highest in wetland for their indices. The other landscape types of $C_{i}$ were smaller, the value of which tended to 0 . Some of $V_{i}$ tended to 0 , such as the landscape types of Rural L, Dry L, sand and bottomland, others had changed from 0 to $0.1 . F_{i}$ was different for different landscape types, the value of which was from 0 to 0.3 . we computed with Kring and mapped the distribution of LERI. The LERI value of each quadrat was divided into five levels of LERI regions: level 1 (0 0.0042), level 2 (0.0043 0.0162), level $3(0.0163 \sim 0.0489)$, level 4 (0.0490 0.0968), and level 5 (0.0969 0.1245).

The distribution of the LERI regions revealed some trends in 2000. The level 5 LERI region was an important habitat to species in wetland. The boundary of the region corresponds to Bayanbulak Natural Park. Swamps and parts of bottomlands were the types of habitat in this region, which were mostly waterfowl breeding and feeding grounds. The flora and fauna species listed in Appendices I, II, and III of CITES (2010) and the National Key Protected Wild Plants List (1999) accounted for 95.3\% of species in the study area. The region was suitable for most birds and plants, resulting in high species richness. The birds in the region were mainly whooper swans, cranes, and a variety of eagles and falcons. The level 4 and 3 LERI regions were considered as buffer areas and transition regions to protect wetlands, and were used by birds and other animals for feeding and migratory stopovers. The level 2 LERI regions were secondary habitats for some birds and animals. They contained Full and Medium G, parts of sand, Rural L, Dry L, and bottomland. Level 1 LERI regions were influenced mostly by natural and human disturbances. Compared to 2000, the biggest change was observed in the level 5 LERI region, which scattered into multiple locations. The distribution range was disrupted to the west of level 5, in the center the buffer area of level 4. To the south, the range decreased back to the center, reducing the gap proportion filled with the level 2 regions. The next paramount change was in the buffer area of levels 4 and 3, where the LERI region increased. In the north, the transition range of level 3 visibly increased. The level 2 region mainly compensated for the lack of a level 5 region, and no obvious changes were detected in level 1 (Fig. 4).

\section{Descriptive Statistics of LERI}

To further research changes in the ecological landscape matrix and the types and sizes of different LERI regions with GIS 9.3, the LERI range and all landscape types in 2000 and 2010 were overlaid. The proportions of all landscapes in the LERI region levels were quantified for the area (Fig. 5, Table 4).

Fig. 5 shows the different landscape types and species contained in the different LERI regions. In 2000 the largest area of the LERI region was level 2. This is followed by level 5 and then levels 4, 3, and 1. Landscape heterogeneity is reflected in the different landscape types in the LERI regions. All landscape types are present in levels 1 and 2, whereas the other levels contained eight types, excluding woodland. The region of every level had a different dominant landscape matrix, which was the major habitat for the main species present. Landscape type and matrix therefore indirectly determined the distribution of the species. For all landscape matrices, wetland and Full G were significant habitats in the study area. Full $\mathrm{G}$ was a major matrix of levels 1,2 , and 3, accounting for $69.72 \%, 84.6 \%$, and $61.17 \%$, 
Table 4. Landscape pattern of area from ecological risk region in Bayanbulak wetland.

\begin{tabular}{|c|c|c|c|c|c|c|c|c|c|c|c|}
\hline \multirow[b]{2}{*}{ Time } & \multirow{2}{*}{$\begin{array}{l}\text { Levels } \\
\text { region }\end{array}$} & \multicolumn{9}{|c|}{ Area of different landscape types in LERI region $\left(\mathrm{Km}^{2}\right)$} & \multirow[b]{2}{*}{ Area } \\
\hline & & Wetland & $\begin{array}{l}\text { Low } \\
\text { C G }\end{array}$ & $\begin{array}{c}\text { Medium } \\
\mathrm{C} \mathrm{G}\end{array}$ & $\begin{array}{l}\text { Full } \\
\text { C G }\end{array}$ & Rural L & Sand & Bottomland & Woodland & Dry L & \\
\hline \multirow{5}{*}{2000} & 1 & 0.01 & 1.02 & 0.48 & 45.03 & 6.65 & 7.67 & 0.25 & 2.50 & 0.97 & 64.59 \\
\hline & 2 & 2.81 & 11.71 & 74.97 & 711.74 & 4.27 & 8.05 & 24.44 & 1.01 & 2.33 & 841.35 \\
\hline & 3 & 25.83 & 0.14 & 12.79 & 76.08 & 1.26 & 1.44 & 5.56 & - & 1.27 & 124.37 \\
\hline & 4 & 87.01 & 0.81 & 6.38 & 60.81 & 0.25 & 0.40 & 1.90 & - & 0.03 & 157.60 \\
\hline & 5 & 695.47 & 0.11 & 1.08 & 9.79 & 0.48 & 0.10 & 0.41 & - & 0.01 & 707.47 \\
\hline \multirow{5}{*}{2010} & 1 & 0.02 & 1.05 & 22.06 & 24.74 & 12.82 & 0.03 & 1.27 & 1.46 & 0.52 & 63.98 \\
\hline & 2 & 2.75 & 35.98 & 275.39 & 446.52 & 10.70 & 32.36 & 96.91 & 1.44 & 1.78 & 903.84 \\
\hline & 3 & 31.78 & 127.29 & 31.31 & 38.43 & 3.50 & 0.49 & 21.29 & - & 0.42 & 254.49 \\
\hline & 4 & 99.95 & 12.54 & 23.48 & 29.81 & 1.56 & 0.39 & 9.12 & - & - & 176.84 \\
\hline & 5 & 479.23 & 0.99 & 4.68 & 6.18 & 0.69 & 0.01 & 4.45 & - & - & 496.22 \\
\hline
\end{tabular}

respectively. For level 4, due to the transition function, wetland and Full $\mathrm{G}$ were both habitats present that accounted for $55.21 \%$ and $38.59 \%$, respectively.

In 2010, the LERI region area, landscape heterogeneity, and matrix all altered. For all region levels, the areas of levels 2 and 5 were still the largest and second largest.
In comparison to the areas in 2000, the area of level 2 increased by $62.49 \mathrm{~km}^{2}$ while the areas of levels 5 and 1 decreased by $211.24 \mathrm{~km}^{2}$ and $0.61 \mathrm{~km}^{2}$, respectively. The areas of levels 3 and 4 had increased by $30.12 \mathrm{~km}^{2}$ and $19.24 \mathrm{~km}^{2}$, respectively. The LERI region of landscape heterogeneity in 2010 changed slightly from that in 2000.

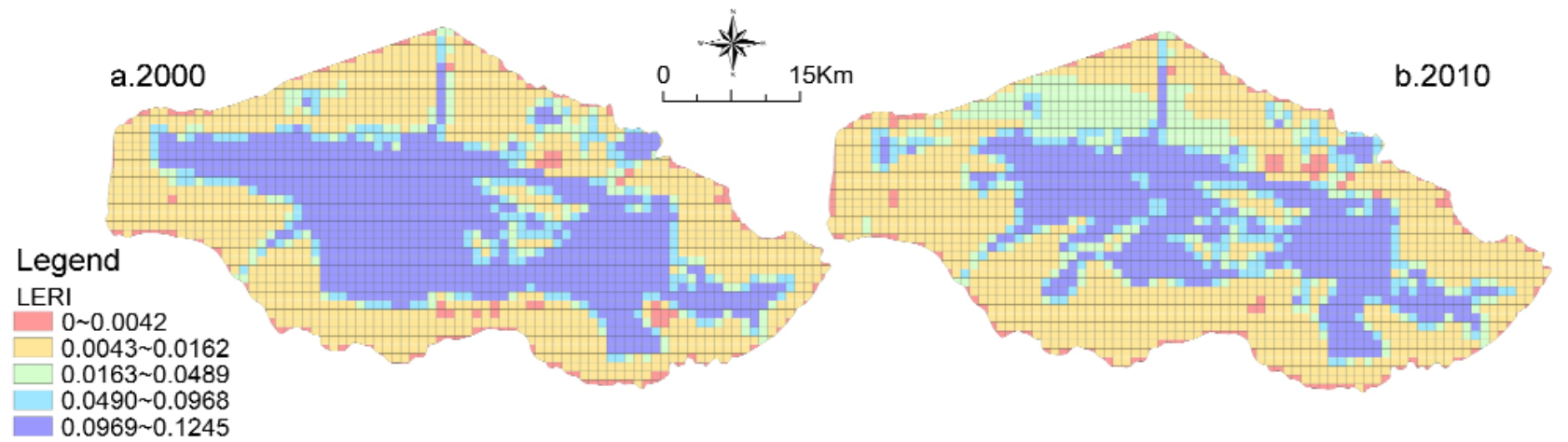

Fig. 4. LERI distribution in the Bayanbulak wetland from 2000 to 2010.
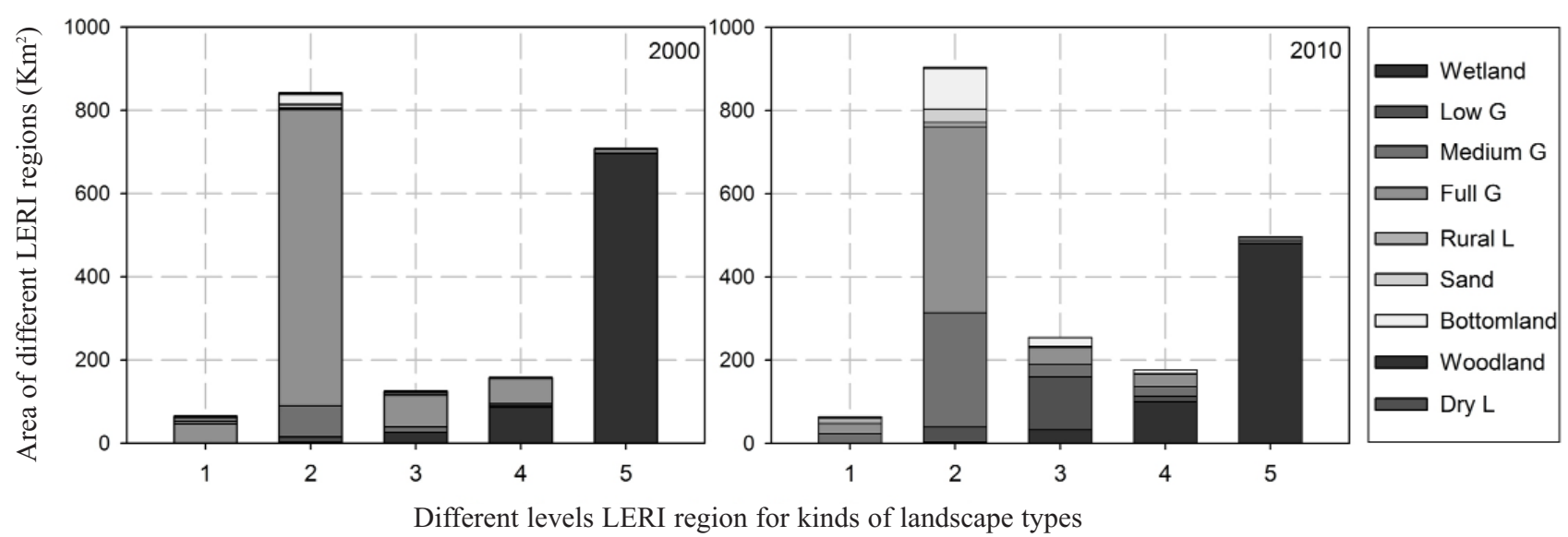

Different levels LERI region for kinds of landscape types

Fig. 5. Landscape types of LERI in Bayanbulak wetland from 2000 to 2010. 
Levels 1, 2, and 3 did not change, but levels 4 and 5 had 7 landscape types. In comparison to 2000, for the matrices of landscape types, Low and Medium G became important habitats. The landscape matrices in the level 1 LERI region were Medium G and Full G, accounting for $34.48 \%$ and $38.67 \%$, respectively. For level 2, the Medium G area increased, although the major landscape matrix remained Full G. The area of Full G was reduced by $32.99 \%$. Low G was the major habitat for level 3, accounting for $50 \%$ of the total area. For the level 4 and 5 regions, the wetland was the major matrix, with area growth observed for different landscape types.

\section{Shifting Weight of Characteristics in Different LERI Regions}

To understand the process of weight shifting in space for different LERI regions, a gravity center model was used to calculate barycentric coordinates. They were then used to map the center of gravity in space, according to the coordinates of the different LERI regions (Fig. 6).

The general trend of the center of gravity in different LERI regions was from east to west. In this direction, the LERI regions were organized into levels $3,4,1,2$, and 5 . The direction of the transformation of gravity was extended to the southwest. The distances around the center of gravity varied widely between the regions of the different levels. The displacement of the level 2 region had the biggest change and extended $18.14 \mathrm{~km}$ to the southwest. The second largest displacement was for the level 1 region, which shifted $16.76 \mathrm{~km}$ to the southwest. The smallest change was for the level 5 region, where the displacement was $6.65 \mathrm{~km}$ to the west. Regions of the other levels shifted more than $10 \mathrm{~km}$ to the southwest. The shifting of the center of gravity for the LERI regions suggested that the regions changed intensively over the 10 years studied. For LERI regions, the direction of gravity was transferred from the northeast to the southwest. The biggest change in direction angle occurred in level 5, the second greatest was in level 2. The smallest change in direction angle was in the level 3 LERI region.

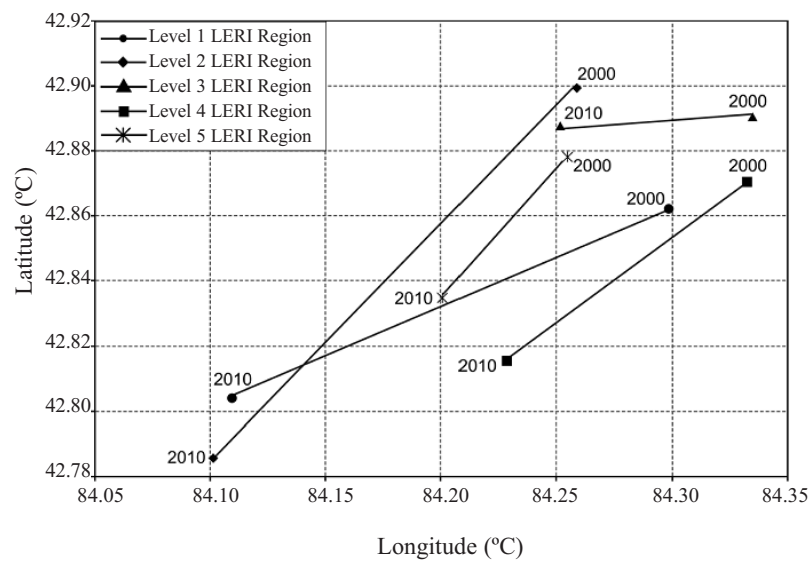

Fig. 6. Changes of ecological risk region centroid in Bayanbulak wetland.

\section{Discussion of Results}

\section{The Change of the LERI Region}

This study established associations between the LERI model, thriving and endangered species, and landscape type to thoroughly investigate the Bayanbulak Natural Heritage Site. The semi-variation function model divided the area into five LERI regions, with a LERI value for each unit (Fig. 4). The gravity-center model was used to quantify the aspect and distance of the LERI regional gravity change (Fig. 6). The results were consistent with the observations in the area. Most importantly, the highest LERI value in the study area corresponded to the national reserve and heritage site core range. Comparisons between the years 2000 and 2010 showed that the levels of the LERI regions had changed. Changes were found in the area size, excursion of distance, and aspect of the LERI region. For individual LERI regions, the number of thriving and endangered species, landscape types, and landscape matrix also changed (Fig. 5).

This paper reported that the establishment of a LERI index can include the theory of landscape ecology and conservation biology. The results from the Bayanbulak Wetland, combined with landscape and species, were more comprehensive than those of the separate studies of individual species and vegetation [41-44, 68]. The LERI model performance was compared with other research on ecological risk, including the types of species and distribution of endangered species that had increased in the evaluation [34, $38,73,74]$. Gravity center models are generally used in the analysis of changes of landscape patterns [76]. This model was used in this study to quantify the specific change of the LERI regions.

TM image selection was not included in the analysis, although a $30 \mathrm{~m}$ resolution may have been suitable for the study area. Ultimately, the resolution was found to be too coarse for researching the landscape types in certain regions. The habitats of species were shown to be related to different landscape types, so the change in distribution of species habitat may have been affected by the image. For the study area, the LERI model provided suitable results that were a good representation of the real-life situation. The species habitat migration, the indictor of species distribution characteristics, and the corresponding protective measures were not clearly reflected. For the assessment of the value of the natural heritage, an important LERI region was investigated for protection. The next step would be to thoroughly study the protective measures for every LERI region, clearly understand the range of different landscape connectivity, and determine the effects of LERI regions on single species.

\section{LERI Region Driving Factors}

Various threatening factors reduce the ecological function and systems of wetlands. These include climate change, biological invasion, human activities, and water pollution $[3,9,10,19]$. The change of the LERI region may correlate with natural and human factors. 
Table 5. Correlation coefficient of ecological risk and environmental factors in Bayanbulak wetland.

\begin{tabular}{|c|c|c|c|c|c|c|}
\hline Correlation coefficient & $\mathrm{X}$ & $\mathrm{Y}$ & DEM & SLOP & TPI & ASP \\
\hline $\mathrm{X}$ & 1 & - & - & - & - & - \\
\hline $\mathrm{Y}$ & $-0.344^{* *}$ & 1 & - & - & - & - \\
\hline DM & $0.055^{*}$ & $0.148^{* *}$ & 1 & - & - & - \\
\hline SLOP & $0.354^{* *}$ & $-0.069^{* *}$ & $0.648^{* *}$ & 1 & - & - \\
\hline TPI & -0.035 & $0.044^{*}$ & $-0.053^{*}$ & $-0.117^{* *}$ & 1 & 1 \\
\hline ASP & $0.179^{* *}$ & 0.004 & 0.026 & $0.088^{* *}$ & 0.003 & $-0.113^{* *}$ \\
\hline LERI & $0.102^{* *}$ & 0.029 & $-0.489^{* *}$ & $-0.269^{* *}$ & $0.043^{*}$ \\
\hline
\end{tabular}

$\mathrm{X}$ - longitude, Y - latitude, DM - elevation, TPI - slope position, ASP - aspect;

**Correlation is significant at the 0.01 level, *Correlation is significant at the 0.05 level

\section{Climate Factor}

As one of the most fundamental natural factors, climate change effects material and energy circulation, wetland productivity, and the landscape pattern of plants and animals [41]. As an alpine wetland, Bayanbulak has special characteristics and climate changes may have had a significant effect on the ecological systems, local climate, the ability of adjusting water resources, and sustainable changes [47]. Climate change can alter the hydrological characteristics and effect the landscape pattern, habitat of plants and animals, and the entire ecological system. Fig. 7 shows that annual precipitation decreased while annual mean temperature increased. Precipitation reached its minimum value in 2003, when temperatures reached a maximum value. The direct influence of climate change was shown by grassland desertification. The LERI of this study relates to species and landscape pattern indices. Climate change was one of the most important factors for species distribution and was also the principal driving force for landscape patterns [48].

\section{Environmental Factors}

The landforms at Bayanbulak reflect the distribution of landscape patterns. Longitude, latitude, and elevation can reveal geographical features in three-dimensional space. Slope and aspect can affect the habitat distribution of plants and animals [17]. The relationship between environmental

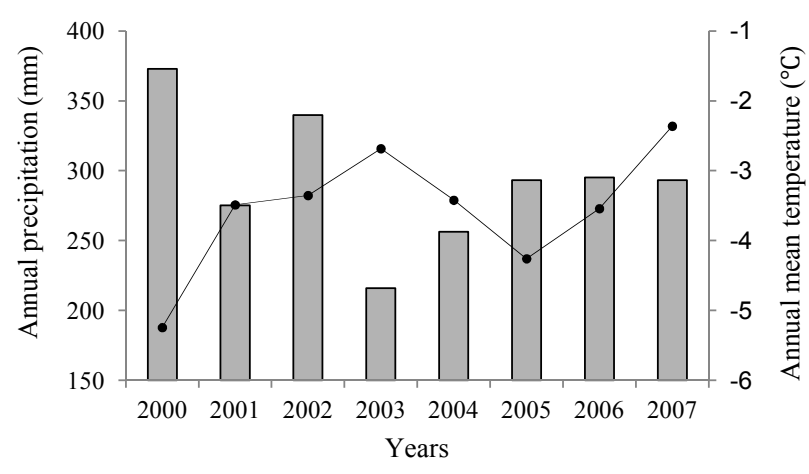

Fig. 7. Annual variations in precipitation and temperature in Bayanbulak wetland. factors (e.g. longitude, latitude, elevation slope, and aspect) and LERI are discussed [13]. According to the DEM data from 2010, we counted data for ecological factors at the center of each quadrat to construct a database. The standardization of environmental factors was then performed in a stepwise regression analysis.

A correlation coefficient ( $r$ ) reflected the degree of correlation among the variables. If $|\mathrm{r}|<0.3$, the degree of correlation was weak; if was in the range $|r|>0.3$ and $|r|<0.7$, the degree of correlation was moderate; finally, if $|r|>0.7$ and $|\mathrm{r}|<1.0$, the degree of correlation was strong. Table 5 shows that the LERI of Bayanbulak clearly correlated with environmental factors, with the exception of latitude ( $\operatorname{sig}>0.5)$. The LERI had a weak correlation with longitude $(r=0.102)$ and aspect $(r=0.043)$. There was a moderate negative correlation with elevation $(\mathrm{r}=-0.489)$, a weak negative correlation with slope $(\mathrm{r}=-0.269)$, and slope position $(\mathrm{r}=-0.113)$ (Table 5).

In order to comprehensively discuss the relationship between environmental factors and LERI, a stepwise regression analysis was used to obtain the following model:

$$
\begin{gathered}
\mathrm{LERI}=0.303 \mathrm{X}+0.299 \mathrm{Y}-1.504 \mathrm{DM}-0.289 \mathrm{TPI} \\
\left(\mathrm{p}<0.005, \mathrm{R}^{2}=0.749\right)
\end{gathered}
$$

The environmental factors of $\mathrm{X}, \mathrm{Y}, \mathrm{DM}$, and TPI were significant at $\mathrm{P}<0.05$. The equation fit was $\operatorname{good}\left(\mathrm{R}^{2}=0.749\right)$. The LERI of Bayanbulak was affected by longitude, latitude, elevation, and slope position.

\section{Human Activities}

Human activities are the main influential factors that result in species extinction and landscape-type changes [40]. Over the 10 years studied, the influence of human activity on the grassland ecosystems showed a "weakstrong-weak" trend. Due to the additive effect of ecological environment and landscape pattern for human activities, the overall influence decreased after 2005 with some remaining traces. Table 6 shows the influence of human activities on landscape level. Patch density (PD), Shannon index (SDI), evenness index (SEI), and mean shape index (MSI) are 
Table 6. The human activity factors and landscape level index change in Bayanbulak wetland.

\begin{tabular}{|c|c|c|c|c|c|c|c|c|}
\hline Year & MD & RD & SR & TN & PD & SDI & SEI & MSI \\
\hline 2000 & 6.32 & 0.04 & 57.60 & 5.50 & 0.05 & 1.08 & 0.49 & 1.83 \\
\hline 2010 & 2.36 & 0.07 & 7.50 & 9.50 & 0.07 & 1.60 & 0.73 & 1.96 \\
\hline
\end{tabular}

$\mathrm{MD}$ - residential density $\left(\mathrm{man} / \mathrm{km}^{2}\right), \mathrm{RD}$ - road density $\left(\mathrm{km} / \mathrm{km}^{2}\right), \mathrm{SR}$ - number of actual grazing (million sheep), TN - number of tourists (Million), PD - patch density (number $/ \mathrm{km}^{2}$ ), SDI - Shannon index, SEI - evenness index, MSI - mean shape index

increased from 2000 to 2010, which reflected the complex relationship between changing landscape pattern, fragmentation, the shape of patches, and human activities.

From 2000 to 2010 the grassland of the wetlands appeared to have experienced desertification, salinization, and degradation [49]. This was due to overgrazing and the disorder of grazing. As a major meadow in Xinjiang, the residents of Bayanbulak Wetland have been historically involved in grazing. Alongside economic growth, the degree of grazing increased after 2000. The number of sheep reached 576,000. Overgrazing and climate resulted in the meadow area seriously deteriorating, with shorter grass and reduced grass productivity. The area of meadow reduced to $533 \mathrm{~km}^{2}$ with rat and locust plagues frequently occurring. The ecological system and structure of the food chain altered. There were 75,000 sheep in the area in 2010, a reduction of nearly 500,000 . Starting in 2005 , the managers of the study area controlled the amount of grazing and built fencing for livestock and sheep. By the end of 2009, a total of $3,804.1 \mathrm{~km}$ of fencing had been built.

Tourist activities resulted in the construction of roads. Between 2000 and 2010, the number of tourists increased from 55,000 to 95,000 . The increased tourism to the scenic site meant that the area was made more accessible and road density (RD) increased from 0.04 to 0.07 $\mathrm{km} / \mathrm{km}^{2}$. The building of tourist infrastructure affected the landscape and the ecological systems. However, the effect of tourists was limited to a specific area and, as a result, was not large enough to damage a vast area of wetland in Bayanbulak.

Policy has a significant effect on ecological conservation. It can alter the distribution of landscape patterns and the habitat of plants and animals. All governmental protective measures prohibited, or limited, human activities within the core area and buffer area in the heritage site. This was especially true for grazing. These measures resulted in some low-cover grassland gradually transforming to middle and high-cover grassland, changing the landscape pattern of the heritage site. Improvements were observed in managed livestock and indigenous species habitats.

Following the Bayanbulak heritage declaration project, the government introduced special laws and regulations to rule the content of protection and management mechanism. The list of activities prohibited in the heritage site was clarified (deforestation, herding, hunting, fishing, herbalism, reclamation, land occupancy, mining, quarrying, sandexcavation, etc.). Regulations of the Kaidou River source and Bayanbulak grassland ecological protection ordinance and the Bayanbulak meadow ecological protection ordi- nance included measures to protect the ecological emigration and rotational grazing in the Bayanbulak area. The livestock were implemented 'laissez-passer' regulation in order to restrict grazing behavior. After the implementation of these policies, the number of sheep decreased by 801,000 and the area of grassland degradation was reduced to $207 \mathrm{~km}^{2}$.

After 2005 all grassland in Xinjiang had implemented ecological emigration and rotational grazing policy to maintain the sustainable development of the ecosystem. Since the project of Bayanbulak heritage was declared, stricter grazing prohibition policies were implemented, in comparison to the rotational grazing policy in external pastures. The grassland ecological environment in the heritage site vastly improved when compared to external pastures; pasture degeneration was effectively relieved, the water conservation capability was significantly enhanced, and the coverage of grassland was more than $90 \%$ of the prairie area. This illustrated that a strict grazing prohibition policy can help restore ecological vegetation in the Bayanbulak area. The planning and policy implementation discussed incorporated pasture block rotational grazing and grazing prohibition, environmental capacity checks, and ratification of other policies. These policy changes must always be strictly followed in order to protect the landscape patterns and ecological security in the heritage site.

\section{Conclusions}

The ecological characteristics of the Bayanbulak world heritage site were analyzed in order to protect its biodiversity and aesthetic value. In this study, appropriate indicators for the landscape and species were selected to establish a LERI model. Using the semi-variation function model, the study area was divided into five regions. A gravity center model was used to quantify specific changes of the LERI region.

The results showed that over 10 years, the landscape characteristics of Bayanbulak changed. The area of Full G decreased by $39.63 \%$ and the NP for Low G decreased. $P_{i}$ for Dry L, wetland, and Full G all decreased, while the $S_{i}$ increased. The $N_{i}$ of Medium G also increased. Species indices changed with landscape types, distribution range, and species class. The values of $C_{i}$ and $V_{i}$ were highest, but the $C_{i}$ of other landscape types tended to 0 .

Spatio-temporal distribution characteristics of LERI showed a decrease in the average value and peak of LERI. Levels of LERI regions changed from a single center to a 
polycentric dispersion area, which turned differentiation to uniformity. Over 10 years, with the different functions for regional levels, the function, area, types, and matrices had noticeably changed in types of landscape patterns. For wetlands, level 5 was a significant habitat for different kinds of flora and fauna species, as well as endangered plants and animals. Other regions had different functions. These included buffer and transition functions. The major matrix of the regions levels changed over the 10 years. Full G, wetland, and Medium $\mathrm{G}$ became important habitats and matrices. The center of gravity for various LERI regions altered intensively, which changed from northeast to southwest. The displacement of level 2 changed drastically, and shifted $18.14 \mathrm{~km}$ to southwest. The direction angle of level 5 changed the most.

While predicting driving factors of LERI regions, climate change was verified as an important factor for species change and the distribution of the LERI region in the study area. LERI was found to be correlated with longitude, aspect, elevation, slope, and slope position to varying degrees. Grazing, tourism, and policy affected landscape patterns on a meso-and micro-scale. Policy altered the landscape pattern and habitat of plants and animals in the shortterm. In order to overcome the limitations of this study, future research must concentrate on protective measures, ranges of different landscape connectivity, grazing areas, and pasture partitions.

\section{Acknowledgements}

Our study was supported by a funded project of western PHD in the University of the Chinese Academy of Sciences (XBBS201210), the National Natural Science Foundation of China (41301163), the Foreign Experts Distinguished Researcher Plan project in the University of Chinese Academy of Sciences (2010T2Z17).

\section{References}

1. KONG F., XI M., LI Y., KONG F., CHEN W. Wetland landscape pattern change based on GIS and RS: A review. J. Appl. Ecol. 24, (4), 941, 2013 [In Chinese].

2. TREBITZ A. S., MORRICE J. A., TAYLOR D. L., ANDERSON R. L., WEST C. W., KELLY J. R. Hydromorphic determinants of aquatic habitat variability in Lake Superior coastal wetlands. Wetlands. 25, (3), 505, 2005.

3. MYERS S. C., CLARKSON B. R., REEVES P. N., CLARKSON B. D. Wetland management in New Zealand: Are current approaches and policies sustaining wetland ecosystems in agricultural landscapes?. Ecol. Eng. 56, 107, 2013.

4. COSTANZA R., DARGE R., DEGROOT R., FARBER S., GRASSO M., HANNON B., LIMBURG K., NAEEM S., ONEILL R. V., PARUELO J., RASKIN R. G., SUTTON P., VANDENBELT M. The value of the world's ecosystem services and natural capital. Nature. 387, (6630), 253, 1997.

5. THAKUR J. K., SRIVASTAVA P. K., SINGH S. K., VEKERDY Z. Ecological monitoring of wetlands in semi-arid region of Konya closed Basin, Turkey. Reg. Envir. Chang. 12, (1), 133, 2012.
6. VASQUES G. M., GRUNWALD S., MYERS D. B. Associations between soil carbon and ecological landscape variables at escalating spatial scales in Florida, USA. Landsc. Ecol. 27, (3), 355, 2012.

7. SAUNDERS D. A., HOBBS R. J., MARGULES C. R. Biological consequences of ecosystem fragmentation: a review. Conserv. Biol. 5, (1), 18, 1991.

8. BRINSON M. M., MALVAREZ A. I. Temperate freshwater wetlands: types, status, and threats. Environ. Conserv. 29, (2), 115, 2002.

9. AN S., TIAN Z., CAI Y., WEN T., XU D., JIANG H., YAO Z., GUAN B., SHENG S., OUYANG Y., CHENG X. Wetlands of Northeast Asia and High Asia: an overview. Aquat. Sci. 75, (1), 63, 2013.

10. JI L., WEN Y. Wetland Ecosystem Services Valuation of Chongming Dongtan. Chin. Agr. Sci. Bullet. 29, (5), 160, 2013 [In Chinese].

11. MINCKLEY T. A., TURNER D. S., WEINSTEIN S. R. The relevance of wetland conservation in arid regions: A reexamination of vanishing communities in the American Southwest. J. Arid. Environ. 88, 213, 2013.

12. WALZ R. Development of environmental indicator systems: Experiences from Germany. Environ. Manage. 25, (6), 613, 2000.

13. YOU W., HE D., WU L., HONG W., ZHAN S., QIN D., YOU H. Temporal-spatial differentiation and its change in the landscape ecological security of Wuyishan Scenery District. Acta Ecol Sin. 31, (21), 6317, 2011.

14. BRANDER L., BROUWER R., WAGTENDONK A. Economic valuation of regulating services provided by wetlands in agricultural landscapes: A meta-analysis. Ecol. Eng. 56, 89, 2013

15. TAFT O. W., HAIG S. M. Importance of wetland landscape structure to shorebirds wintering in an agricultural valley. Landsc. Ecol. 21, (2), 169, 2006.

16. KAHARA S. N., MOCKLER R. M., HIGGINS K. F., CHIPPS S. R., JOHNSON R. R. Spatiotemporal patterns of wetland occurrence in the prairie pothole region of Eastern South Dakota. Wetlands. 29, (2), 678, 2009.

17. SHI H., YANG Z., HAN F., SHI T., LUAN F. Characteristics of temporal-spatial differences in landscape ecological security and the driving mechanism in Tianchi scenic zone of Xinjiang. Prog. Geogr. 32, (3), 475, 2013.

18. MUSACCHIO L. R. The scientific basis for the design of landscape sustainability: a conceptual framework for translational landscape research and practice of designed landscapes and the six Es of landscape sustainability. Landsc. Ecol. 24, (8), 993, 2009.

19. MITA D., DEKEYSER E., KIRBY D., EASSON G. Developing a wetland condition prediction model using landscape structure variability. Wetlands. 27, (4), 1124, 2007.

20. CASTANEDA C., HERRERO J., CASTERAD M. A. Landsat monitoring of playa-lakes in the Spanish Monegros desert. J. Arid. Environ. 63, (2), 497, 2005.

21. VERBEIREN S., EERENS H., PICCARD I., BAUWENS I., VAN ORSHOVEN J. Sub-pixel classification of SpotVegetation time series for the assessment of regional crop areas in Belgium. Int. J. Appl. Earth Obs. Geoinf. 10, (4), 486, 2008.

22. JOHNSTON R. M., BARSON M. M. Remote sensing of Australian wetlands: An evaluation of Landsat TM data for inventory and classification. Mar. Freshw. Res. 44, (2), 235, 1993.

23. BAKER C., LAWRENCE R., MONTAGUE C., PATTEN D. Mapping wetlands and riparian areas using Landsat ETM+ imagery and decision-tree-based models. Wetlands. 26, (2), 465, 2006. 
24. WRIGHT C., GALLANT A. Improved wetland remote sensing in Yellowstone National Park using classification trees to combine TM imagery and ancillary environmental data. Remote Sens. Environ. 107, (4), 582, 2007.

25. PIMM S. L., JENKINS C. N., ABELL R., BROOKS T. M., GITTLEMAN J. L., JOPPA L. N., RAVEN P. H., ROBERTS C. M., SEXTON J. O. The biodiversity of species and their rates of extinction, distribution, and protection. Science. 344, (6187), 2014.

26. KULIK M. Changes of Biodiversity and Species Composition of Molinia Meadow Depending on Use Method. Pol. J. Environ. Stud. 23, (3), 773, 2014.

27. DODD D. W. After the Grizzly: Endangered Species and the Politics of Place in California. Pub. Hist. 36, (2), 2014.

28. REN H., JIAN S., LIU H., ZHANG Q., LU H. Advances in the reintroduction of rare and endangered wild plant species. Sci. China-Life Sci. 57, (6), 603, 2014.

29. RAPPORT D. J. Ecosystems not optimized: A reply. J. Aquat. Ecosyst. Stress. Recov. 2, (1), 57, 1993.

30. RESCIA A. J., WILLAARTS B. A., SCHMITZ M. F., AGUILERA P. A. Changes in land uses and management in two Nature Reserves in Spain: evaluating the social-ecological resilience of cultural landscapes. Landsc. Urban Plan. 98, (1), 26, 2010.

31. DOBSON A. P., BRADSHAW A., BAKER A. Hopes for the future: restoration ecology and conservation biology. Science. 277, (5325), 515, 1997.

32. DAI X., MA J., ZHANG H., XU W. Evaluation of ecosystem health for the coastal wetlands at the Yangtze Estuary, Shanghai. Wetl. Ecol. Manag. 21, (6), 433, 2013.

33. GULINCK H., M GICA M., DE LUCIO J. V., ATAURI J. A. A framework for comparative landscape analysis and evaluation based on land cover data, with an application in the Madrid region (Spain). Landsc. Urban Plan. 55, (4), 257, 2001.

34. XU X., LIN H., FU Z., BU R. Regional ecological risk assessment of wetland in the Huanghe River Delta. Acta. Scient. Natural. Universitat. Pekin. 37, (01), 111, 2001 [In Chinese].

35. FRIEDMAN S. K., ZUBE E. H. Assessing landscape dynamics in a protected area. Environ. Manage. 16, (3), 363, 1992.

36. HULSHOFF R. M. Landscape indices describing a Dutch landscape. Landsc. Ecol. 10, (2), 101, 1995.

37. FORMAN R. T. Some general principles of landscape and regional ecology. Landsc. Ecol. 10, (3), 133, 1995.

38. SONG X., XIAOWEN L., BAI J., LI C., ZHENG Y., JIAO $\mathrm{S}$. The ecological sensitivity evaluation in Yellow River Delta National Natural Reserve. Acta Ecol Sin. 29, (9), 4836, 2009 [In Chinese].

39. ROGERS K. S. Ecological security and multinational corporations. Environ. Change. Sec. Proj. Rep. 3, 29, 1997.

40. TANG B., LI J., LUO J. Review on the ecological risk assessment of wetland. J. Anhui. Agr. Sci. 37, (13), 6104, 2009 [In Chinese].

41. YANG Q., CUI C. Impact of Climate Change on the Surface Water in Bayanbuluk Alpine-Cold Wetland in the Tianshan Mountainous. J. Glaciol. Geocryol. 27, (3), 397, 2005 [In Chinese].

42. CAI D., MA M. A comparative study of auditory centers of the medulla oblongata in Lizards and Toads. Wild animals. (02), 11, 1997 [In Chinese].

43. LI W., WANG Y. Vegetation community of the wetland in Bayinbu Lake swan conservation of Xinjiang. Ecol. Sci. 26, (5), 443, 2007 [In Chinese].
44. DING T., LI Y., LIU Y. Relationship Between the Change of NDVI and the Main Vegetative and Climate Factors in Bayinbuluk Grassland. Remote. Sens. Inform. (1), 53, 2009 [In Chinese].

45. CHEN X. Physical geography of arid land in China, 1st ed.; Science publishing: Beijing, pp. 630-660, 2010 [In Chinese].

46. Xinjiang Tianshan. United Nations Educational, Scientific and Cultural Organization. Available on:

http://whc.unesco.org/en/list/1414/documents/ 20 February 2014.

47. LI Q., LI L., BAO A. Snow Cover Change and Impact on Streamflow in the Kaidu River Basin. Resour. Sci. 34, (1), 91, 2012 [In Chinese].

48. HE G., LI K., SONG W., GONG Y., LIU X., HU Y., TIAN C. The fluxes of carbon dioxide, methane and nitrous oxide in alpine grassland of theTianshan Mountains, Xinjiang. Acta Ecol Sin. 34, (3), 674, 2014 [In Chinese].

49. ZHANG J., ZHANG R., XI W., AN S. Evaluation system of determining optimal stocking rates of Tianshan mountain steppe: A case study in Xinyuan County,Xinjiang. Prat. Sci. 27, (12), 134, 2010 [In Chinese].

50. The Operational Guidelines for the Implementation of the World Heritage Convention. Available on: http://whc.unesco.org/en/guidelines/opguide-en.pdf 20 February 2014.

51. ALZUA A., O'LEARY J. T., MORRISON A. Cultural and heritage tourism. J. Tourism. Stud. 9, (2), 2, 1998.

52. BIANCHI R. V. The contested landscapes of World Heritage on a tourist island: The case of Garajonay National Park, La Gomera. Internatl. J. Herit. Stud. 8, (2), 81, 2002.

53. SMITH M. A critical evaluation of the global accolade: the significance of World Heritage Site status for Maritime Greenwich. Internatl. J. Herit. Stud. 8, (2), 137, 2002.

54. JHA S. Can Natural World Heritage Sites promote development and social harmony?. Biodivers. Conserv. 14, (4), 981, 2005.

55. JIMURA T. The impact of world heritage site designation on local communities - A case study of Ogimachi, Shirakawamura, Japan. Tourism Manag. 32, (2), 288, 2011.

56. ROCHON G. L., JOHANNSEN C. J., LANDGREBE D. A., ENGEL B. A., HARBOR J. M., MAJUMDER S., BIEHL L. L. Remote sensing as a tool for achieving and monitoring progress toward sustainability. Clean Technol. Environ. Policy. 5, (3-4), 310, 2003.

57. RINDFUSS R. R., WALSH S. J., TURNER B., FOX J., MISHRA V. Developing a science of land change: challenges and methodological issues. Proc. Natl. Acad. Sci. U. S. A. 101, (39), 13976, 2004.

58. ARAG N R., OESTERHELD M., IRISARRI G., TEXEIRA M. Stability of ecosystem functioning and diversity of grasslands at the landscape scale. Landsc. Ecol. 26, (7), 1011, 2011.

59. LUO G., ZHOU C., CHEN X. Stability of patches of oasis landscape in arid areas: A case study of Sangong River Watershed, Xinjiang, China. Chin. Sci. Bull. 51, (1), 92, 2006.

60. TURNER M. G., ROMME W. H., GARDNER R. H., O'NEILL R. V., KRATZ T. K. A revised concept of landscape equilibrium: disturbance and stability on scaled landscapes. Landsc. Ecol. 8, (3), 213, 1993.

61. GULLINO P., LARCHER F. Integrity in UNESCO World Heritage Sites. A comparative study for rural landscapes. J. Cul. Herit. 14, (5), 389, 2013.

62. HAN F., YANG Z., LIU X., DI F. Impact assessment and protection of outstanding landscape integrity in a natural heritage site: Fairy valley, Kanas Nature Reserve, Xinjiang, China. J Mt. Sci. 8, (1), 46, 2011. 
63. FJELLSTAD W., DRAMSTAD W. E., STRAND G.-H., FRY G. L. Heterogeneity as a measure of spatial pattern for monitoring agricultural landscapes. Norsk Geografisk Tidsskrift. 55, (2), 71, 2001.

64. STOVEL H. Effective use of authenticity and integrity as world heritage qualifying conditions. City. Time. 2, (3), 3, 2007.

65. JIANGUO W. Paradigm shift in ecology: an overview. Acta Ecol Sin. 16, (5), 449, 1996.

66. RAPPORT D. J. Sustainability science: an ecohealth perspective. Sustain. Sci. 2, (1), 77, 2007.

67. WU J. Landscape sustainability science: ecosystem services and human well-being in changing landscapes. Landsc. Ecol. 28, (6), 999, 2013.

68. ZHAO R., CHEN Y., SHI P., ZHANG L., PAN J., ZHAO H. Land use and land cover change and driving mechanism in the arid inland river basin: a case study of Tarim River, Xinjiang, China. Environ. Earth Sci. 68, (2), 591, 2013.

69. TOVAR C., SEIJMONSBERGEN A. C., DUIVENVOORDEN J. F. Monitoring land use and land cover change in mountain regions: An example in the Jalca grasslands of the Peruvian Andes. Landsc. Urban Plan. 112, 40, 2013.

70. TIAN H., SUN Q., DU J. Ecological Comprehension Evaluation on Jingxin Wetlands. Wetland. Sci. 12, (1), 122, 2014 [In Chinese].

71. YOU W., HE D., WU L., HONG W., ZHAN S., HUANG D., QIN D., YOU H. Spatial-temporal Variation of Landscape Service Value and Its Correlation with Ambient Environmental Factors in Mountain ResortsA Case Study of
Wuyishan Scenery District. J Mt. Sci. 30, (1), 113, 2012 [In Chinese].

72. HU H., LIU H., HAO J., AN J. The urbanization effects on watershed landscape structure and their ecological risk assessment. Acta Ecol Sin. 31, (12), 3432, 2011 [In Chinese].

73. XIE H., WANG P., HUANG H. Ecological Risk Assessment of Land Use Change in the Poyang Lake Eco-economic Zone, China. Int. J. Environ. Res. Public Health. 10, (1), 328, 2013.

74. MA X., LU Z., LIN T. Ecological risk assessment of Yancheng Coastal Wetland. Mar. Environ. Sci. 29, (4), 599, 2010 [In Chinese].

75. YAO R., YANG J., LIU G. Spatial Variability of Soil Salinity and Moisture and Their Estimations by CoKriging MethodA Case Study in Characteristic Field of Yellow River Delta. J. Soil. Water. Conserv. 20, (5), 133, 2006 [In Chinese].

76. DUAN H., WANG T., XUE X., GUO J., WEN X. Spatialtemporal Evolution of Aeolian Desertification and Landscape Pattern in Horqin Sandy Land: A Case Study of Naiman Banner in Inner Mongolia. Acta Geograp Sin. 67, (7), 917, 2012 [In Chinese].

77. LIU H., LIN Z. Responsive mechanism of species extinction to the habitat destruction at different time scales. Shengtaixue Zazhi. 24, (10), 1215, 2005 [In Chinese].

78. DIAO W., YAN Z. Mechanism of species extinction. Bulletin. Biol. 42, (02), 12, 2007 [In Chinese]. 
